\title{
New Broadcasting Ecosystem and the Second Screen Phenomenon in Turkey: Case Study on the Serial Insider
}

\author{
Sevda Ünal ${ }^{*}$, Mutlu Binark ${ }^{* *}$, Selin Çetindağ ${ }^{* * *}$ \\ * Faculty of Communication, Çukurova University, Turkey \\ ** Faculty of Communication, Hacettepe University, Turkey \\ *** Social Sciences Institute, Hacettepe University, Turkey
}

\begin{abstract}
Traditional television broadcasting has shown a significant change with the convergence to the new media environment. This convergence has changed the traditional ways of television content production and consumption. The audience has become the most important actor in the broadcasting industry, and new mediums and platforms, such as second screen applications and social TV, have gained importance in television broadcasting. This article discusses the transformation of television broadcasting from the second screen phenomenon and the new broadcasting ecosystem through the case of the Turkish serial Insider. The participation of the audience as a producer and consumer, the changing industry strategy, and the new ways of brand integration in this new broadcasting environment were examined through content analysis. The analysis results reveal the audience management strategies of the Turkish broadcasting industry and the audience's position as producer and consumer in this new ecosystem.
\end{abstract}

Keywords: Television industry, broadcasting ecosystem, content production, convergence, second screen, audience

\section{Introduction}

Today, we are witnessing a new media ecology in which traditional and new media environments intersect. This intersection, called convergence, has changed traditional industrial production and mass consumption in television broadcasting, and it has created the basis for the formation of a new ecosystem. This new ecosystem and the convergence of different mediums has also changed the audience's approach to television.The multiscreen platform-viewing experience has become more common with more and more simultaneous media applications.

In this ecosystem, the television industry now creates specific content for certain programs and directly interacts with viewers through social media platforms. The use of the "second screen", which is the main component of this new ecosystem, has the function of inviting the viewer to produce and share content with the television industry. Together with the use of new media applications, the social television phenomenon has changed the way the audience experiences content. Participation in the narrative flow through the second screen and social media applications enriches the viewer experience, on the one hand, and provides a powerful viral marketing opportunity for broadcasters, on the other. 
In this study, the transformation of television broadcasting from the second screen phenomenon and the new broadcasting ecosystem in Turkey is discussed through the serial Insider, which was introduced by Ay Yapım. Insider was broadcasted on Show TV during the period of 2016-2017, and it is an important example that reveals the changing form of audience participation through second screen environments and the social media strategies of the television industry. In short, the aim of this study is to propose an image of the transformation of the traditional broadcasting industry in Turkey and to discuss the new position of the viewer as a part of the networked public. We first provide an overview of the changing media ecosystem and television broadcasting industry. Second, with the Turkish serial Insider, we reveal new forms of viewing experiences and audience management strategies in the television industry by applying content analysis on the serial's hashtags.

\section{New Broadcasting Ecosystem and Second Screen Case: The Role of Convergence}

Digitalization affects our way of experiencing the media and changes media industry professionals' way of work. With the adoption of Internet technologies by the masses and the transition to web 2.0 technologies on the Internet, the media ecosystem has undergone a profound shift. Through digitalization, traditional media intersects with different and diverse media environments that connect it to the network. This intersection has caused an important shift in both the media industry and television industry. This shift has been defined by the term "convergence" by both industry professionals and scholars, and this term has thus become a buzzword since the 1990s (Storsul\&Stuedahl, 2007, p.9) in defining new media and the new broadcasting ecosystem.

James Hay and Nick Couldry (2011), in their article "Rethinking Convergence/Culture", propose four definitions related to "convergence" to emphasize the changing forms of viewing: as "a description of synergy among media companies and industries, as the multiplication of 'platforms' for news and information, as a technological hybridity that has folded the uses of separate media into one another (e.g. watching a television broadcast on a cell phone), and as a new media aesthetic involving the mixing of documentary and nondocumentaryforms." For Henry Jenkins (2006), convergence should be understood not as a fixed relationship but as an ongoing process or sequence of the intersections between different media systems. When we talk about convergence, we refer to not only technological aspects but also cultural and social aspects. He placed "media convergence" at the center of "culture" (Hay\&Couldry, 2011, p.473). Jenkins (2004) sees convergence as an old concept with new meanings that reflects a situation in which multiple media systems coexist and media content flows through different platforms. It changes the relationship between existing technology, industry, markets, gender, and audiences. Convergence has two dimensions: It is both a corporate-driven (top down) and consumer-driven (bottom up) process. The consumer-driven process refers to the participatory culture in which the audience's active engagement is necessary. The audience in this convergence culture is active, migratory, and not loyal to media companies. However, according to Jenkins, the participatory culture debate is not based on the assumptions of 
technological determinism (2013, p.269). Media convergence should not be considered simply a technological change, as it changes the relationship between existing technologies, industries, markets, genres, and audience. In this context, convergence describes technological, industrial, cultural, and social changes together. Jenkins views a contrast with hypotheses that have tried to define convergence through purely technological factors-digitization in particular (Matthews, 2010).

In this new media and broadcasting ecosystem, we come across with new production and consumption processes. These new processes have changed television-viewing practices. New mediums and platforms have begun to accompany such viewing practices. New mediums such as smart phones, tablets, and notebooks that enable multiscreen activity called social TV and new platforms of social media such as Twitter, Facebook, and Instagram constitute the main characteristics of this new media ecosystem.

This new media and new broadcasting ecosystem bring with them new discussion regarding the position of television. In other words, recent trends in viewing habits have triggered the question, "Is traditional TV coming to an end?". The author of this statement argues that the nature of television is undergoing some radical shifts and that these shifts are signs of a landmark in terms of how television is produced, distributed, and consumed. Like Jenkins (2006), Elihu Katz (2009) discusses the future of television and suggests that television has always been a medium in transition. In particular, in his essay "The End of Television? Its Impact on the World (So Far)", Katz (2009) states that with the integration of the Internet and new media, television has evolved along two axes. The first axes is from having the same content to having differentiated content, and the second axes is from watching together to watching alone. Another scholar, John Ellis (2000), defines television broadcasting in three phases. He called the first phase (1950s to 1980s) "scarcity." In this phase, there was a limited number of channels and a habit of watching together in common. Ellis defines the second phase with the word "plenty." In this phase, satellite and cable and competition reigned, there were TV sets in every room of the home, and the number of channels increased. The last phase is "infinite choice." In this phase, we can view whatever we like. Moreover, we can choose the time and the medium (Katz, 2009, p.7). Jakob Bjur (2012), who is against the argument of the "end of television", states that the death of television remains in theory. In contrast, the television audience becomes even more individualized, and this individualization has increased steadily with network technologies (pp.175-176). Following this discussion, we can say that television broadcasting is moving from classical television broadcasting to interactive television broadcasting. Thus, business models in the television sector have also changed. In the new broadcasting ecosystem, content production is not limited to just television content; it is also planned for different digital mediums. Thus, a multi-faceted production structure has emerged. David Marshall (2010) has particularly drawn attention to the multi-platform structure of television broadcasting. With this structure, the viewing experience has changed, where a new viewing experience can take place at different times and different locations, with different screens. Elizabeth Evans (2015) refers to Henry Jenkins' conceptualization of "transmedia storytelling" to explain this new viewing experience. Jenkins (2007) defines transmedia storytelling "as a process where integral elements of a fiction get dispersed systematically across multiple delivery channels for the purpose of creating a unified and coordinated entertainment experience". According to Evans, the use of different screens has changed storytelling on 
television, as it has layered the experience for the audience and synchronized second screen applications with the convergence of the timeliness of television narratives. In short, media convergence encourages a new participatory culture that supports the audience's active participation by giving average people the tools to archive, annotate, appropriate, and recirculate content (Jenkins, 2001). In the studies of Jenkins, fan subcultures and fan participatory culture seem to be at the center of the new media ecosystem (Matthews, 2010, p.6). The participation of audiences to the industry circle as both consumer and producer by using social media platforms has revealed a new aspect of television viewing; this is called "social television". James Blake (2017) notes that television broadcasting always creates socialization through programs, but social television goes beyond bringing together different television content communities, and it thus allows inclusion and identification in a particular context/theme.

Social television gives opportunities to the audience to intensively interact with media content using a variety of communication tools. This interaction with content has led to some changes in the writing and marketing of television scenarios (Arrojo, 2015, p.38). Roberta Pearson states that "The digital revolution has had a profound impact upon fandom, empowering and disempowering, blurring the lines between producers and consumers, creating symbiotic relationships between powerful corporations and individual fans, and giving rise to new forms of cultural production" (2010, p.1). The advantages of social television in terms of the television industry can be listed as social ratings through social media, which is a new rating measurement system, and the development of an advertising strategy targeting viral marketing. In addition, this free and voluntary labor of the audience, in favor of the industry, operates as both data and value. The television industry uses second-screen tools to attract its audience. Moreover, hashtags, various activities, opening chatrooms, sharing posts, etc., are used in an audience-management strategy in the television industry (Blake, 2017, p.8). In terms of the television industry and advertisers, second-screen usage is an important audience management tool to reach the target group. Therefore, in the new broadcasting ecosystem, the use of the second screen is going to increase as a tool for audience management. In short, all types of data related to a program that are entered by the audience emerge as a social rating. Social ratings affect the ratings and permanence of programs in traditional media.

\section{Development of the New Broadcasting Ecosystem and the Second Screen Case in Turkey}

Television broadcasting in the new broadcasting ecosystem now takes place through multiple media platforms. Considering ratings and advertisers, various new strategies will inevitably be created for audience management. For example, the industry creates official fan pages about program for audience management through the second screen, and audiences are directed to these platforms for interaction. Web TV, video sharing sites, video streaming sites, and social media platforms are components of the new publishing ecosystem. Twitter, Instagram, YouTube, and Facebook are preferred for sharing various types of descriptive information, pictures, and videos related to the contents of television broadcasts. However, in order to receive online feedback and create a chat environment simultaneously with television, create 
hashtags, and feature on trending topic lists, Twitter has relatively come to the forefront.The convergence of television broadcasting with new media platforms in Turkey has occurred parallel with the development of Internet technologies and the spread of social media platforms. In Turkey, especially after 2010, television organizations have started to use social media actively to support traditional media content. Social media platforms such as Facebook and Twitter and video sharing platforms such as YouTube formed the basic platforms for such a strategy (Dikmen, 2017, pp.433-436). Using the new media platforms to support TV content, TV content was offered on different new media platforms and through different promotion channels and strategies.

The use of hashtags as an audience management strategy was first seen in 2011, during the airing of the TV series For My Father (Babam İçin) on the commercial Turkish channel Fox TV. Then, in 2012, one of the episodes of the sitcom A Man and Woman (Bir Erkek Bir Kadın) aired with the hashtag \#bencocukken (\#WhenIwasaKid). Another example of second screen usage is North-South (Kuzey Güney), which was broadcasted on Kanal D during the years 2011-2013 and produced by Ay Yapım. On an episode from March 7, 2012, the leading women character of North-South, Cemre, created an account on Twitter (https://twitter.com/Cemre Cay) and shared tweets simultaneously. The serial Waiting for the Sun (Güneşi Beklerken), which was produced by D Production, broadcasted on Kanal D between July 2013 and July 2014, and D Production created a fan page called Zeyker. Zey refers the leading female character, Zeynep, and Ker refers to the leading male character, Kerem. On this page, information about Zeynep and Kerem, music, and fan messages were shared (Sezen, 2016, p.173). For the serial Magnificent Century (Muhteşem Yüzyıl), an interactive comic book was designed. Then, in 2017, a comprehensive mobile game for the serial was produced in Turkey. The mobile game was available for free on the App Store and Google Play, and the game was designed entirely in accordance with the characters. In the first 24 hours of its release, the game ranked first for most downloads.

\section{New Broadcasting Ecosystem and Audience Management: Insider}

The Turkish TV serial Insider (İçerde) aired on the Turkish commercial mainstream TV channel Show TV between the period of September 2016 and June 2017 on each Monday at prime time. The serial consists of 39 episodes. The serial Insider is a successful example for discussion on both the changing ecosystem of the Turkish television industry and the audience's position in broadcasting, producing, sharing, and distributing content. Insider was produced by Ay Yapım, which is one of the leading Turkish production companies. ${ }^{1}$

\footnotetext{
${ }^{1}$ Ay Yapım was founded in 2005. Since then, Ay Yapım has produced drama series, formats, and weekly and daily shows. With the series Endless Love (Kara Sevda), Ay Yapım won its first Emmy for best telenovela. Endless Love has been broadcasted in 60 countries. For further information, please see http://ayyapim.com/about
} 
Insider represents a flexible adoption of both Internal Affairs, produced in 2002 in Hong Kong, and Departed, produced in 2006 in the U.S. It is a story of two brothers, Sarp and Umut, looking for each other. Umut was kidnapped at a very young age. Then, his mother and his brother Sarp dedicated their lives to finding him. ${ }^{2}$ Yamaç Okur, the executive producer of Insider, states that "Both Instagram and Twitter's social media management went very well. With 500,000 followers on Instagram and 60-70,000 followers on Twitter, they are the two platforms that have incredible interaction with the audience. For interaction, interpretations made by the audience are very important in the television industry" (July, 2017). Show TV's social media team managed Insider's official accounts on Scorp and Groop, and Insider's official accounts on YouTube, Twitter, and Instagram were managed by the production company Ay Yapım. In addition, various accounts on the platforms Twitter, Instagram, Facebook, and YouTube were created by fans of Insider.

The most important reason why viewers are interested the second screen is the flexibility. For this reason, creating original content has been the number one priority for television companies. However, in no way should the industry interfere with the audience in choosing the access time and place, as one of the most important factors in the viewing experience is the desire for flexibility (Duncan \& Krommendam, 2014). Hence, the degree of the flexibility that the content provides to the audience is an important factor in determining the success of the content.

There is another important function of the second screen for the television industry in Turkey. In Turkey, the airtime of serials lasts an average of three hours. Thus, it is particularly important to keep the audience in front of the screen for a long time. In his interview, Okur (July 2017) emphasizes the role of social media in securing the audience's attention to the traditional screen. In Insider, in addition to social media platforms that appeal to a broad audience, such as YouTube, Twitter, Instagram, and Facebook, content was also produced for new social media platforms, such as the Turkish chat applications Scorp and Groop. Thus, interaction with the audience was maintained.

Scorp is a social media application that was developed by the students İzzet Zakuto and Sercan Işık of Koç University in Turkey in 2015. Its slogan is "Millions of millennials telling their stories on any subject. Now, it's your turn!" University students are considered the target audience, and the application has three language options: Turkish, English, and German. It allows users to share comments on specific categories with 15-second videos. The application reached 10 million users in June 2017. Insider interacts with Scorpels through the broadcast channel by displaying episode hashtags. Groop is another social media application that was used for Insider. It is a mobile app that focuses on group conversations. Groups of 6 persons, who know each other or do not know each other, meet in a 15-minute talk session and share ideas with each other. Groop defines itself as a social chat platform, but it also incorporates play into it. In Groop, instant discussions were made about the latest episode of Insider, and Insider's episode hashtag was shared on Show TV with the Groop symbol.

There are some other social media platforms that were used by Ay Yapım for audience management. For example, on the website of Show TV (http://www.showtv.com.tr/dizi/tanitim/icerde/1681) under the section

${ }^{2}$ The full story can be read at http://ecchorights.com/series/insider 
of serials, users can obtain information about Insider. This information on Insider is classified under the titles "Serials, scenes, fragments, news, photo gallery, cast". After it aired on TV, the audience could watch Insider through this platform uncensored. YouTube is an important social media platform that helps make content viral around the world in a very short time. Insider also has an official account on YouTube, which has approximately 1 million followers. It is also possible to access a wide range of content produced by the audience related to Insider via YouTube.

Regarding web TV, we can mention two initiatives that have been developed currently in Turkey. The first is Blu TV, which has been active since January 2016 and is owned by Doğan Holding. ${ }^{3}$ It is a prepaid service and works with a membership. Puhu TV is another web TV channel in Turkey. It has been active since December 2016 and is owned by Doğuş Holding ${ }^{4}$. As it is free of charge, users can watch content both with or without a membership. Unlike Blu Tv, Puhu TV's main source of income is ads, as same with traditional television channels. On both platforms, one can watch Turkish serials that are shot for only for these platforms and are not shown on television. Until episode 19, Insider could be watched through its official YouTube account, but after an agreement with Puhu TV, access to episodes in Turkey via YouTube account was blocked.

Regarding the use of social media, executive producer Okur states that Facebook is an effective platform for interaction but is difficult to manage. Therefore, they have preferred Twitter and Instagram for audience management on the second screen (Okur, July 2017). Twitter, which is now almost synonymous with the second screen, allows its users to share a message with 140 characters $^{5}$. Twitter was effectively used by both the production firm Ay Yapım and the Insider audience, and Insider is thus a successful example of creating a virtual discussion environment on Twitter, especially through hashtags. Instagram is a social networking platform that was specially developed for photo and video sharing via smartphones. Insider's official Instagram account "icerdetvdizi" has 432,000 followers. During the 39 episodes, 1490 posts were shared.

Shazam is one of the applications that was used for the first time with Insider to watch a scene at 360 degrees. Shazam is known as an online music scanning application. In 2011, the "Shazam for TV" application was launched. Through shazaming scenes from TV shows, movies, and sequences, the user is redirected to the relevant page. Audience members who launched this application on their phone were able to watch the shooting scene of the female leading character, Melek, at 360 degrees and had the opportunity to see the person who shot Melek. This was realized under Fiat sponsorship. Melek's shooting scene has been shazamed 53,700 times. Okur explains the process of selecting Melek's shooting scene for the Shazam application:

\footnotetext{
${ }^{3}$ In the media business, Doğan Holding had been operated in the fields of newspaper, magazine and book publishing, television and radio broadcasting and production, Internet, digital platforms, and printing and distribution. However, they sold all their media institutions to Demirören Group in late March2018.

${ }^{4}$ Doğuş Group is active in eight core businesses fields, including financial services, automotive, construction, media, tourism and services, real estate, energy, and entertainment.

${ }^{5}$ On November 7th 2017, Twitter announced that it would roll out longer tweets to virtually all of its users, doubling the traditional 140 character limit to 280 characters.
} 
"In fact, it was something we had been waiting so long to do. We've been looking for a scene like that for about 15 episodes. It was an application we did with Fiat. We did not see who killed Melek in the scene. We put the camera in a way that everywhere could be seen by using Shazam app. Then, we asked the audience to find the murderer by using Shazam. With the 360-degree angle of the camera, you can see the murderer" (July 2017).

Virtual reality creation was effectively accomplished through Shazam in this scene. However, in fact, in the serial titled Filinta: An Ottoman Detective, which was broadcasted on Tuesday evenings on TRT 1(Turkish Radio Television) between 2014 and 2016, the Shazam application was first used. For the first time in Turkey, before broadcasting, the audience could watch a 5-minute part from the first episode of Filinta via Shazam on the mobile app. This was called a "preview." The application was also announced on the official Twitter account of TRT 1.

\section{Methodology}

In this study, using Insider, new forms of audience participation and industry strategies in audience management are discussed through content analysis. Content analysis has different definitions in its historical development. Bernard Berelson describes content analysis as "a research technique for the objective, systematic, and quantitative description of manifest content of communications" (cited Gökçe, 2001, p.7). Content analysis by incorporating objective reading principles can also be defined as a "second reading" that serves to identify items that affect the individual without being seen (Bilgin, 2014, p.1). Unrecognized concepts and themes in a descriptive approach are also revealed through content analysis. Thus, the collected data are conceptualized, logically organized, and categorized, and the themes describing the data are identified (Yıldııım\&Şimşek, 2003, p.163; Braun\&Clarke, 2006). Through categorization in content analysis, the unrelated material is combined with a logical link, and the information is transformed into analyzable units (Wang, 2015, p.24). Content analysis is used by researchers in the field of communication studies, especially in the field of Internet studies and social media research, in order to categorize big data and collect unrelated material under a theme as one of the main methods.

In this study, the social media platforms Twitter and Instagram were chosen for the research universe, and content analysis of publicly available tweets and Instagram posts on the serial Insider was then conducted, as Twitter and Instagram played a key role in the audience management strategy of the Insider's production firm. Content analysis was conducted on Twitter and Instagram separately.

Twitter and Instagram are the two social media platforms that are actively used in community building. In the example of Insider, episode hashtags were key in directing the audience, and the Insiders audience then shared their feelings, ideas, criticisms, etc., through hashtags. Thus, shares related to Insider were 
compiled and analyzed through hashtags. However, on content on the official Instagram account created by Ay Yapım, "icerdedizitv", was analyzed. Through Instagram, Ay Yapım shared content to increase interactivity and participation and used the platform to share brands appearing on Insider.

Insider built a wide-ranging online community that engages all over the Internet, and Ay Yapım provided its audience with useful, shareable information about the serial. Okur states that for the social media strategy of Insider, they broadcasted trailers on TV and on social media platforms throughout the whole week, andthey announced episode hashtags from social media. As a result, they were able to start debates about the episodes (July, 2017). Hashtags for every episode determined by Ay Yapım thus played an important role in its audience management strategy. In this regard, Marvick and boyd (2016) note that hashtags provide a common platform for discussion, creating a communicative structure for the program that is followed and creating a sincere conversation environment. The audience was encouraged to chat and produce content on Insider both during and after broadcasting as a part of Ay Yapım's content and audience management strategy.

\section{Insider on Twitter}

Here, we review audience discussion on Twitter, which can be classified by hashtags. Hashtags on Twitter are used to explicitly contextualize content, and they are therefore seen by users as a sign of the topics covered in their tweets. In other words, hashtags on Twitter and Instagram are used to identify common issues in messages and to contextualize messages (Jurgens et al., 2011). In this study, hashtags are considered in order to contextualize messages posted for every episode of Insider. Through 39 episodes, Insider became a trending topic on Twitter on both Turkey's list and the world list. According to the social media research company Somera's data, a total of 516,453 tweets were posted in the first four episodes of Insider ${ }^{6}$. Given the number of tweets throughout the 39 episodes andthe time constraints of research, it is not possible to examine all the data constituting the research universe. As seen in this study, when the universe transcends a dimension that can be investigated both materially and in terms of time, sampling is preferred. Two episodes were thus selected randomly for each month as part of the 10-month broadcasting period. Paul J. Lavrakas (2008) defines random sampling as "a variety of selection techniques in which sample members are selected by chance, but with a known probability of selection". After the episodes were identified for every month, tweets were collected. Twitter's advanced search option was used to collect tweets sent under selected hashtags. Advanced search has filtering options that allows user find very specific content (Wadlington, 2016). The broadcasting date of the episode, the episode hashtag, and the serial name were the keywords to collect tweets through the advanced search option.

\footnotetext{
${ }^{6}$ http://www.showtv.com.tr/dizi/haber/1310814-ekranlarin-yeni-fenomeni-icerde.
} 
Using the Google search engine and episode hashtags, the number of tweets posted for every episode was searched. Accessed data are presented in Table 1. While some of the hashtags were derived from the series name, some of them are in the form of a word or a sentence appropriate to the theme of the episode.

Table 1: Serial Insider Episode Hashtags and Tweet Numbers Posted per Episode

\begin{tabular}{|c|c|c|c|c|c|c|c|}
\hline $\begin{array}{l}\text { Episode } \\
\text { Number }\end{array}$ & $\begin{array}{l}\text { Release } \\
\text { Date }\end{array}$ & $\begin{array}{l}\text { Episode } \\
\text { Hashtags }\end{array}$ & $\begin{array}{l}\text { Tweet } \\
\text { Number }\end{array}$ & $\begin{array}{l}\text { Episode } \\
\text { Number }\end{array}$ & $\begin{array}{l}\text { Release } \\
\text { Date }\end{array}$ & $\begin{array}{l}\text { Episode } \\
\text { Hashtags }\end{array}$ & $\begin{array}{l}\text { Tweet } \\
\text { Number }\end{array}$ \\
\hline 1 & 19.09 .2016 & \#içerde (inside) & 73,000 & 2 & 26.09 .2016 & \#içerde (inside) & 56,000 \\
\hline 3 & 03.10 .2016 & \#içerde (inside) & 21,102 & 4 & 10.09 .2016 & $\begin{array}{l}\text { \#içerdeyim } \quad\left(I^{\prime} m\right. \\
\text { inside })\end{array}$ & --- \\
\hline 5 & 17.10 .2016 & \#içerdeyim (I'm inside) & --- & 6 & 24.10 .2016 & \#içerdeki (insider) & --- \\
\hline 7 & 31.10 .2016 & \#içerdemisin (Are you inside) & --- & 8 & 07.11 .2016 & $\begin{array}{l}\text { \#içerdemi (Is he } \\
\text { inside) }\end{array}$ & --- \\
\hline 9 & 14.11 .2016 & $\begin{array}{l}\text { \#MestanıKimÖldürdü (Who } \\
\text { killed Mestan?) }\end{array}$ & 44,121 & 10 & 21.11 .2016 & $\begin{array}{l}\text { \#içerdeler (They } \\
\text { are inside) }\end{array}$ & 43,219 \\
\hline 11 & 28.11 .2016 & $\begin{array}{l}\text { \#TakTakTakaTak } \\
\text { (KnockKnockKnockingKnock) }\end{array}$ & 52,262 & 12 & 05.12 .2016 & $\begin{array}{l}\text { \#benkimim (who } \\
\text { am I) }\end{array}$ & 49,771 \\
\hline 13 & 12.12 .2016 & \#içerde (inside) & 22,866 & 14 & 19.12.2016 & $\begin{array}{l}\text { \#patronkim (who is } \\
\text { the boss) }\end{array}$ & 14,126 \\
\hline 15 & 26.12 .2016 & \#iyimiyiz (Are we Ok?) & 28,807 & 16 & 09.01 .2017 & \#içerde (inside) & 26,189 \\
\hline 17 & 16.01 .2017 & $\begin{array}{l}\text { \#melekikimkurtaracak (who } \\
\text { will save Melek?) }\end{array}$ & 16,340 & 18 & 23.01.2017 & $\begin{array}{l}\text { \#umutiçin(for } \\
\text { Umut) }\end{array}$ & 18,524 \\
\hline 19 & 30.01 .2017 & $\begin{array}{ll}\text { \#oyuniçindeoyun } & \text { (game } \\
\text { within the game) }\end{array}$ & 19,436 & 20 & 06.02.3017 & $\begin{array}{l}\text { \#nefesnefese (out } \\
\text { of breath) }\end{array}$ & 18,109 \\
\hline 21 & 13.02.2017 & \#kardeşim (my brother) & 25,450 & 22 & 20.02.2017 & $\begin{array}{l}\text { \#kimkazanacak } \\
\text { (who will win) }\end{array}$ & 30,479 \\
\hline 23 & 27.02.2017 & $\begin{array}{l}\text { \#güçlüoynayankazansın } \\
\text { (who play strong wins) }\end{array}$ & 14,513 & 24 & 06.03.2017 & $\begin{array}{l}\text { \#yolunsonu (end of } \\
\text { the road) }\end{array}$ & --- \\
\hline 25 & 13.03 .2017 & \#filmbaşlıyor (film is starting) & 24,702 & 26 & 20.03.2017 & $\begin{array}{l}\text { \#benimmahallem } \\
\text { (my neighborhood) }\end{array}$ & -- \\
\hline 27 & 27.03.2017 & $\begin{array}{l}\text { \#enzorkarar (the toughest } \\
\text { decision) }\end{array}$ & 15,022 & 28 & 03.04 .2017 & $\begin{array}{l}\text { \#filminsonu (end of } \\
\text { the film) }\end{array}$ & 88,303 \\
\hline 29 & 10.04 .2017 & $\begin{array}{l}\text { \#enbüyüksır (the biggest } \\
\text { secret) }\end{array}$ & 23,087 & 30 & 17.04 .2017 & $\begin{array}{l}\text { \#kardeşim (my } \\
\text { brother) }\end{array}$ & 21,600 \\
\hline 31 & 24.04 .2017 & $\begin{array}{l}\text { \#obirmelek \#anıbiriktir (she } \\
\text { is an angel, save memories) }\end{array}$ & 44,874 & 32 & 01.05 .2017 & \#birader (brother) & 25,087 \\
\hline 33 & 08.05 .2017 & \#hesapgünü (doomsday) & 43,491 & 34 & 15.05 .2017 & $\begin{array}{l}\text { \#soluksuziçerde } \\
\text { (breathless inside) }\end{array}$ & 41,945 \\
\hline 35 & 22.05 .2017 & $\begin{array}{l}\text { \#içerdeyizabi (we are inside } \\
\text { bro) }\end{array}$ & 105,504 & 36 & 29.05.2017 & \#yılmazbrothers & 72,255 \\
\hline 37 & 05.06 .2017 & \#annem (my mom) & 148,916 & 38 & 12.06 .2017 & $\begin{array}{l}\text { \#kardeşleriçerde } \\
\text { (brothers inside) }\end{array}$ & 109,982 \\
\hline 39 & 19.06.2017 & $\begin{array}{l}\text { \#içerdefinal } \\
\text { \#sonkeziçerdeyiz (insider } \\
\text { final) }\end{array}$ & 200,516 & & & & \\
\hline
\end{tabular}


As previously mentioned, Insider was broadcasted every Monday, during prime time, between 21:00 and 24:00. To analyze the larger corpus of Twitter data on episode hashtags, using random sampling, the first 50 tweets posted at the beginning of the episode and the last 50 tweets posted before the final scene were recorded. In total, within 20 episodes, 2000 tweets were included in the content analysis. After reviewing the tweets, categorization was made through key words. Key words give us clues about the audience's motivations in live tweeting. Five main categories were identified: expressing emotional content, informing, expressing an opinion, criticizing, and producing humor.

Expressing emotional content involves the direct or indirect use of emotional expressions indicating love, hate, hope, excitement, resentment, sadness, celebration, etc. Studies show that audiences react emotionally to television content. For this reason, emotions play an important role in social television (Buschow, Schneider\& Ueberheide, 2014). Tweets that we evaluated under emotional content focused onthe important character Mert's struggle to find his family, the difficulties encountered by the character Sarp in his search for his brother, their failure to come together, the characters' sorrows, the death of a major character on Insider, the moment of the reunion of the brothers, and the relationships of couples. These tweets include the expression of love, hate, hope, excitement, resentment, sadness, and celebration. Moreover, the audience'sexpression of love and hate toward the stars of Insider, images and emojis shared about it, memes, and images and videos produced related to Insider were also evaluated under this category ${ }^{7}$. Okur (2017) notes that one of the hashtags is especially designed as an emoji: "We attached importance to emojis, and we always wanted users to express their emotions with emojis. We always asked users to express their feelings with emojis. For example, what does Coşkun, a bad guy, do for you-this emoji or that emoji? How do you describe this scene, etc? We always try to direct the audience to use emojis". This strategy aims to strengthen the interaction between the audience and narrative.

\footnotetext{
${ }^{7}$ To ensure research ethics and not harm the users, ordinary users' accounts and their content were anonymized in this
} study (Binark et al., 2017). 
Image 1: Example to the Expressing Emotional Content Category

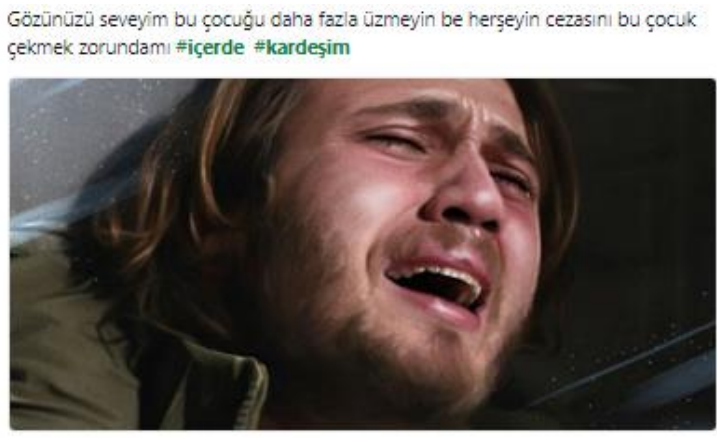

Please, don't upset him anymore. Does this child have to suffer \#insider \#mybrother

Informing characterizes the practice by the production company, the broadcaster, or users of sharing various types of information about Insider in different formats, adding an additional information layer via hyperlinks. Under this category, we can see the dissemination of information on Insider. In addition, we can see other media organizations sharing about Insider and about the cast of Insider, giving links to news, videos, and images.

Image 2: Example to the Informing Category

Show TV o @ShowTV . 1 May
siçerde yeni bölümüyle Show TV de başlad! Iyi seyirler... \#birader @icerdetvdizi

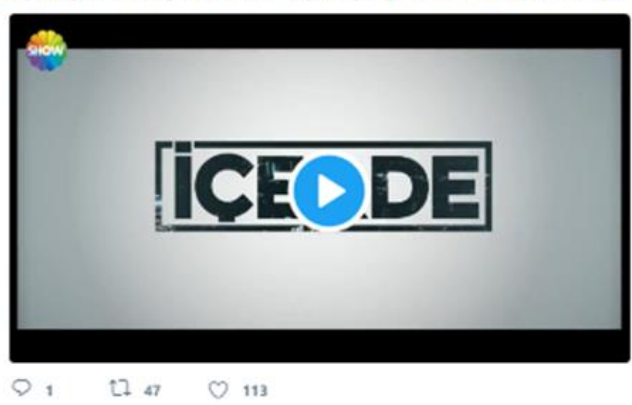

Insider's new episode has just started on Show TV! Enjoy it...\#brother

Expressing an opinion refers to an audience member commenting on Insider's cast, plot, scenarios, dialogues, staging, etc. In addition, dialogues shared by the audience are evaluated under this category. Tweets under this category could be in the form of commenting on the scene, sharing dialogues of the cast, and sharing images about a scene. Audience members find script errors and criticize both the scriptwriter and director of the series; they also make suggestions to the production firm by rewriting the scenarios of the serial. 
Image 3: Example to the Expressing an Opinion Category

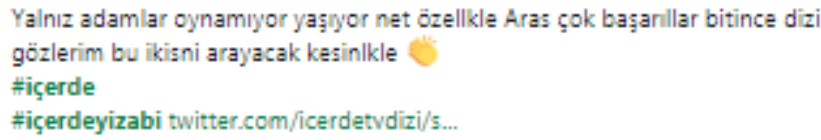

Guys are not playing, they are living the scene. Good luck Aras. I will miss both of them when the series ends. \#insider \#weareinsidebro

Criticizing is categorized as negative feedback from the audience about the cast, plot, scenarios, scenes, and such expressions. Under this category, there are various types of criticisms directed at the cast, plot, scenarios, scenes, director, producer, and even the number of ads.

Image 4: Example to the Criticizing Category

\#kardesim \#icerde @icerdeDizisiTV yaziklar olsun ya sacmaladiniz iyice. Artik izlemicem izlettirmicem! Kardes olduklarini ogrenemediler!
Shame on you! Bullshit! I don't watch anymore and don't let others watch. They they did not learn that they were brothers.

Producing humor is categorized as humorous contents on the serial provided the audience as a source of inspiration. Creative content productions related to Insider made by the audience were also evaluated under this category. For example, the character Coşkun, who is in the role of "bad guy" in the series, kidnapped Mert and thus separated him from his family. However, in the latest episode, he united the two brothers and was therefore declared a hero by the audience with humorous language. Similarly, Alyanak plays a mafia member who constantly changes sides. This characteristic feature of Alyanak is highlighted in the humorous language used by the audience. 
Image 5: Examples to the Producing Humor Category
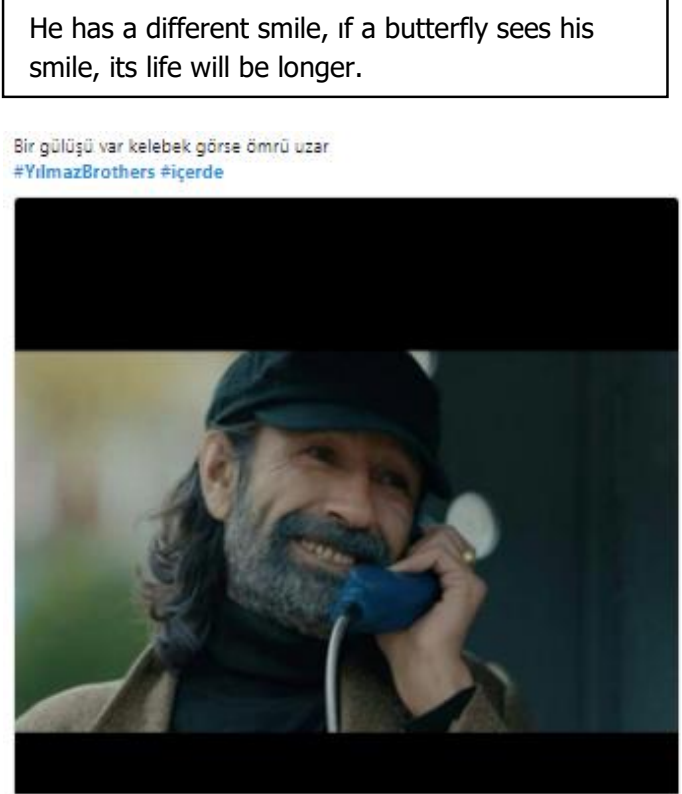

Which turns faster, washing machine or fidget spinner? I think you.

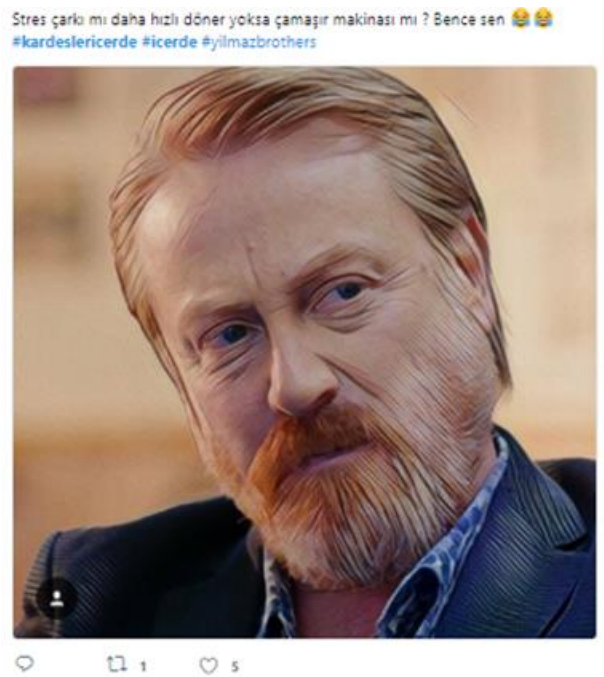

Some fans have opened accounts for fictional characters in the series and assigned themselves a role through these accounts (Harrington, 2016, p.332). With this role, fans portray the character in a narrative in social media and rewrite the narrative in a new platform. Expressions, memes, and comments on images used in these accounts were evaluated under the category of humor production. The categories determined by the content analysis have also revealed the contribution made by the audience to content production and distribution. With this content, the audience makes two types of contributions to the television industry: providing data to publishers and contributing to market expansion. Ralp Rivera, Future Media Director at the BBC, explains how Twitter content provides data to broadcasters:

"One of the things that we will be doing differently in the past is to engage with the people formerly known as the audience, meaning that we will become much more cognizant of who you are and what your relationship is with us throughout your day and your week and as you move from one of our services to another. We know who you are; we know your interests and what your usage patterns are, and then, we start to tailor our services around you and bring you the best of what we have available across TV, radio and online "(Duncan \& Krommendam, 2014, p.4).

Content shared by the audience on Twitter contributes to the diversification of the story in the narrative and the development of subplots. This also contributes to the development of the market for the content. Viewers 
are trying to access the content at appropriate times with various means and to participate in the distribution of the content through the use of social media (Duncan \& Krommendam, 2014, p.11). The content obtained from the viewer and the benefits offered to the industry through this content appear to be free of charge. In other words, the viewer's time has turned into free and effective labor. Stephen Harrington states that productive fans have contributed to the marketing of programs and added revised value to the advertisement activity embedded in the broadcast of the program. For this reason, the free labor experience is exploitative (2016, p.332). Research has shown that the social television phenomenon both reveals the pleasure and interests of the viewer and provides vital value for marketing and advertising (Quintas-Froufe and González-Neir, 2014). As a prosumer, what the viewer does has an important place in the content development strategies of the broadcasting industry. A research conducted in 2013 by the international research company Nielsen (2013), titled "The Follow-Back: Understanding the Two-Way Causal Influence Between Twitter Activity and TV Viewership" reveals a correlation between the number of tweets posted about a program and the increase in the number of views for a program on traditional television. In addition, tweets that the audience produces voluntarily, even with passion, form a database for online advertising and marketing, as well as behavioral and emotional research.

Hashtags function as a bridge between the serial and its audience. Through hashtags, the audience can be informed about the theme of the current episode. The audience's tweets and replies can make the serial more visible both nationally and internationally. The production firm can determine the policy for the following episodes based on the feedback from the audience. The audience also functions both consumer and producer of content, and they contribute to the distribution of content.

\section{The Instagram Account of Insider: Behind the Scenes, the Whipping of Curiosity, and the Relation to Brands}

In this section, Insider's official Instagram account, "\#içerdedizitv" was examined, and five categories were identified to classify data. These categories were identified according to posts sent by the production firm of Insider. The first is "Reminders about Insider" which can be provided, for instance, to give a place to specific scenes from the serial and the broadcasting trailers, before or after the broadcasting of the serial, and to ask questions about the content. Through these contents, the audience remains tied to the narrative of the serial and to the relationships between characters (conflict, tension, love, missing), and in social media, the debate about the serial constantly remains live. To share their thoughts, viewers were provided with a temporary living room, which is a communal character, and the audience continued to produce and consume content on this medium. Ay Yapım asked questions about content such as places where the audience wanted the series to be shot and musics that they wanted to hear, so the viewer was invited to produce content. These questions were supported with gifs (Okur, July 2017). 
Image 6: Example to the Reminders about Insider

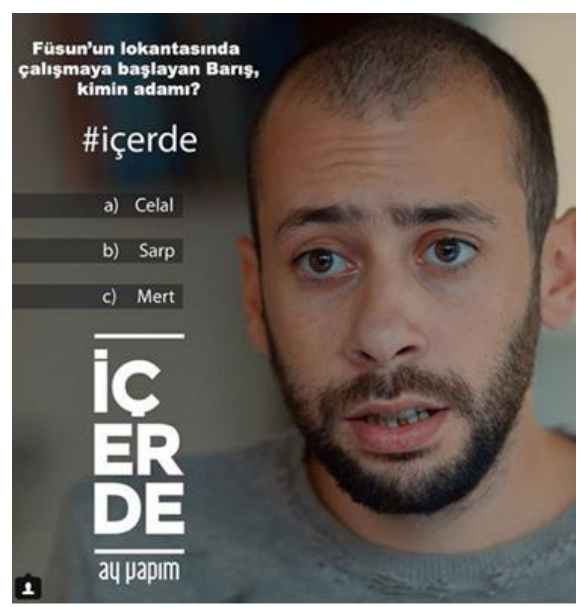

Barış started to work at Fusun's restaurant. Who is working for?

In interacting with viewers, Insider could transfer the content flow to the viewer through the production of pictures or music, arrangements, competitions, questions, and discussions. For example, by organizing competitions, a community spirit and enthusiasm among the audience were created. Moreover, with audience involvement in production, the content reaches a wider audience. Insider has used two hashtags on Instagram that would increase interaction with the audience: \#TakTakTakaTak (knockknockknockingknock) and \#Kardeşim(mybrother) \#Anıbiriktir(savememory). Insiders episode 11's hashtag \#TakTakTakaTak is a rhythmical sound that the character Coşkun made with his ring. At a competition announced on the official Instagram account of Insider, the audience was asked to produce and record this sound with different tools and to send them. It was announced from Insider's Instagram account that the winning clip would be published from the official account. With the hashtag \#Kardeşim\#Anıbiriktir, photographs were collected from the audience's family albums, and these photos were shared in the end credits. 
Image 7: Example to a Competititon

Make your video with the rthym of \#knockknockknockingknock and send us. One of the Insider audience whose video will be chosen, can get to chance to visit the set! Last day is Monday!!!

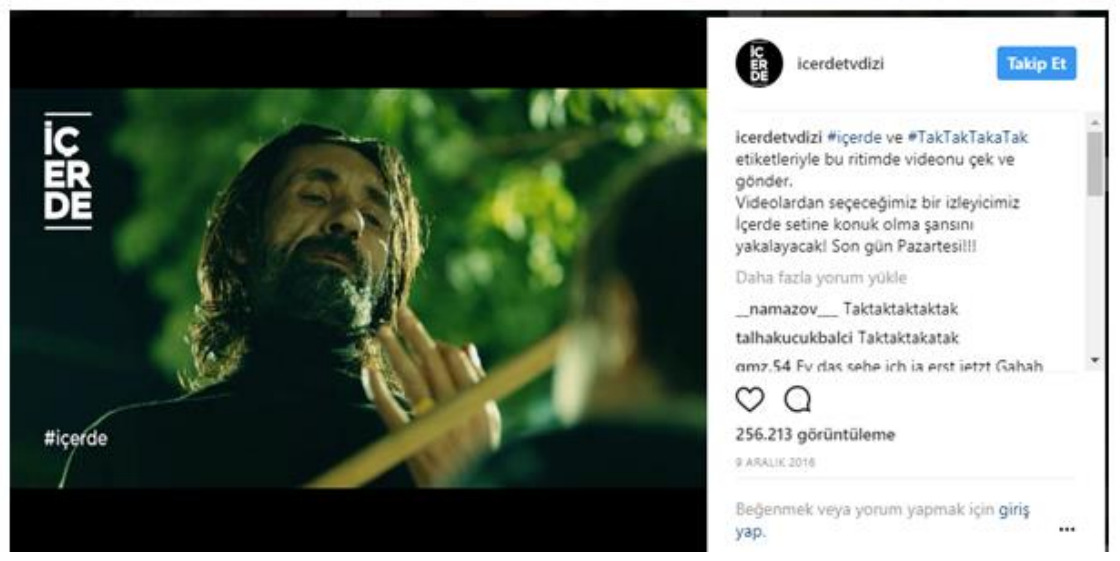

After Insider, the following season, a new Turkish series was produced by Ay Yapım. The new serial, the Pit (Çukur) broadcasts on Show TV. Mert Karadağ/Umut Yılmaz, played by Aras Bulut İynemli, one of the main characters on Insider, is seen in the role of Yamaç Koçovalı in the Pit. Apart from the other main characters, many secondary characters from Insider also appear on the Pit. Unlike Insider, interaction with the Pit is mostly taking place via Instagram. The social media strategy for the Pit in many ways is similar to that for Insider. However, in contrast to Insider's social media strategy, in the Pit, Ay Yapım introduced a new strategy that the audience can listen to their favorite song, especially in the rap genre. After the broadcasting of the episode, the audience can view the video of the song from the Instagram or YouTube account of the Pit. In addition, through Instagram, the audience can request songs to be played on the Pit. Insider's audience management differs from that of other serials in Turkey. This difference arises from the production company, Ay Yapım, which is a pioneer in terms of audience management. The production team strictly follows the international television industry and applies new audience management strategies.

Backstage content can be produced and presented by the industry about an ongoing serial. This content sharing is especially important for fans in terms of showing empathy for and relating to the characters. Backstage content sharing, apart from supporting the narrative, helps establish a more sincere bond between serials and the audience, for instance, by showing the daily life of producing the show. On the one hand, viewers can get clues about the content of the serial; on the other hand, they can witness the daily life practices of the actors and the drama team. The best example of backstage content that gives clues about Insider is the post that ends the debate about the death of the character Melek. Melek, who was the leading female character of Insider, was shot in the final scene of the 30th episode. In episode 31, viewers saw the Melek's death, but on social media, there were some discussions about Melek's death. For some viewers, she did not die. After the day of the 31st episode was broadcasted, Bensu Soral who played Melek 
on Insider, posted a photo on her Instagram account that gave information about the backstage of the serial. With this photo, she shared emotional content and said goodbye to Insider. On social media, this photo and explanation ended the discussion about Melek's death.

Image 8: Example to the Backstage Content

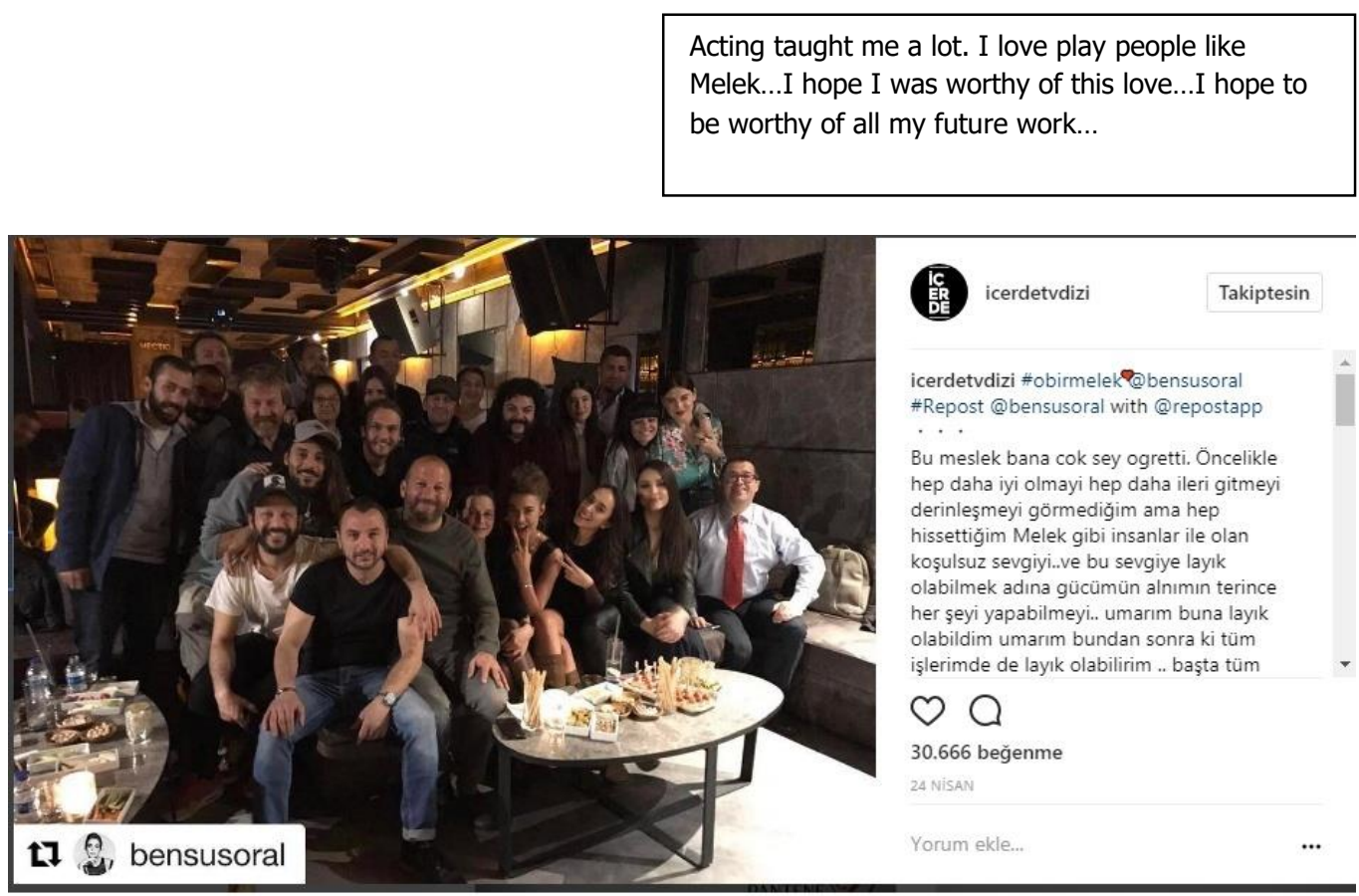

The broadcasting industry incorporates brands into the story in order to include a viral marketing component in the narrative. As well known, Instagram is one of the best mobile apps for brands to share attractive and creative stories and reach their target audience a high-quality environment (Kirkpatrick \& Tode, 2016). Instagram, as an image-focused platform, creates the opportunity to tell a story centered on visual images. One of the advertising strategies of Insider was to incorporate brands in scenario. Doğtaş furniture can be shown as an example. After the broadcasting of Insider, viewers' interactions with this brand on Instagram became visible.

On the Instagram account of Insider, Doğtaş furniture announced which Doğtaş product was chosen for Mert by Eylem. And then asked to the audience "Which one did you choose?" and marketed its product in this way. This firm was among the supporters of the social responsibility project in which Insider was incorporated in.

Today, businesses are evaluated in terms of not only the contribution that they provide to the economy but also the solutions they propose to social problems and their sensitivity to the needs of society. In this context, various institutions and organizations, with a practice called social responsibility, show the public that they consider the interests of society (Peltekoğlu, 2016, p.201). Social responsibility practices provide 
a two-way benefit to institutions: institutions or brands establish an emotional connection with the community, and through this connection, they are thus differentiated from other institutions by creating a positive brand image.

Image 9: Example to the Brand İncorporation
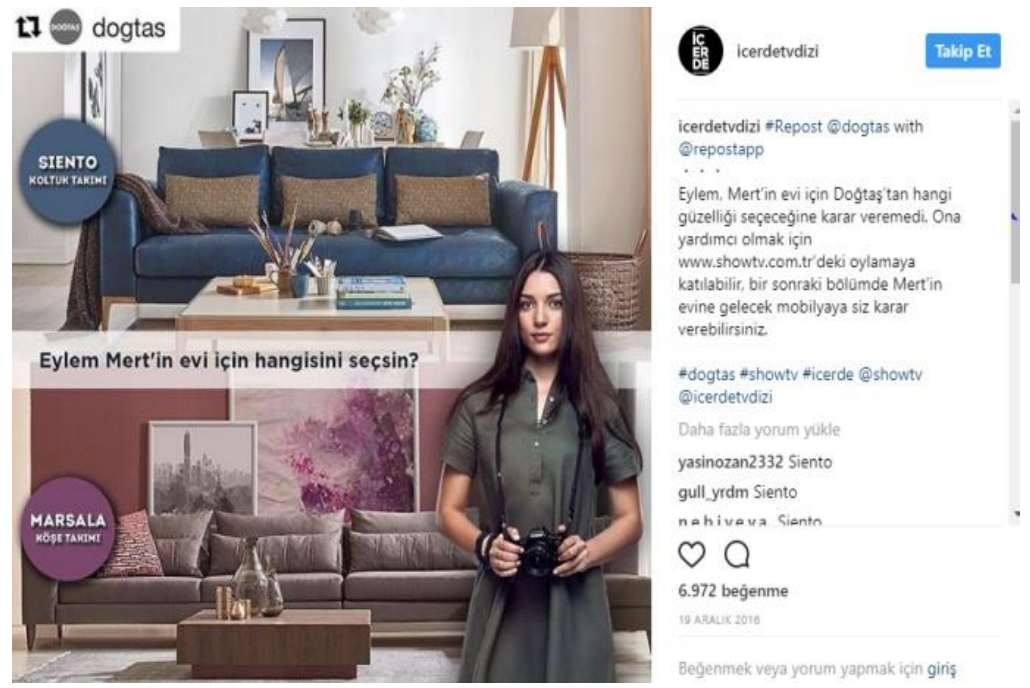

Which one of them should Eylem choose for Mert's house?

Ay Yapım engaged in social responsibility as a strategy in content production and management. For instance, Insider's incorporation with OMO, a home cleansing brand, was implemented a social responsibility project in support of a sports and rehabilitation center to be established in Tekirdağ. Okur (2017) states that they have conducted some researches to realize a project in support of the children, as we know Insider's story is related to children living on the streets. He also states that serials which create serious economic value today should be involved in these kinds of social responsibility projects. A football match was organized under this project with the participation of the audience, and the final episode of the series was shown at the congress center in İstanbul with the participation of the audience and all the cast. The revenues of both events were also donated to the project. In addition, in orderto increase awareness on the project and provide support to the project with SMS messages by the audience, the actors and actresses of Insider called for support through social media. 
Image 10: Example to the Social Responsibility

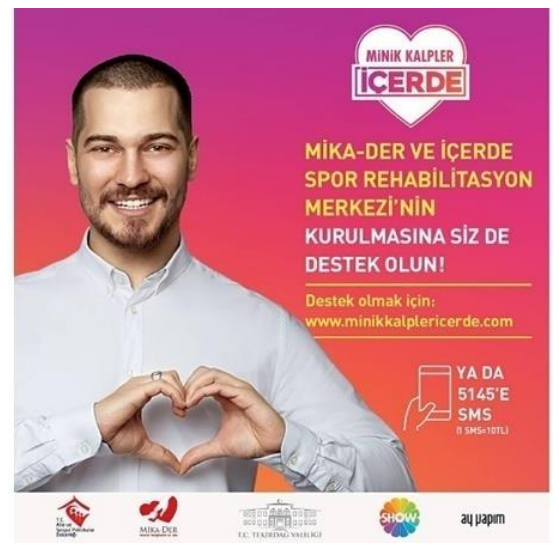

Support to the establishment of Insider and Mika-Der rehabilitation center.

\section{In Lieu of a Conclusion: FromAudience Contribution to Narrative to Value Creation}

Developments in new communication technologies have changed the traditional understanding of broadcasting, especially business models in the television industry. As a result of developments in the television industry, we have been witnessing significant changes in the television ecosystem. This new ecosystem can be defined with concepts such as convergence, participatory culture, the second screen, and social television. The audience plays an important role in the consumption, distribution, and reproduction of content in this new ecosystem. Broadcasting should not be considered to concern only traditional TV; rather, the understanding of broadcasting must be grasped together with new viewing experiences and the media ecology interacting with the viewer. The transformations in the television industry in Turkey, especially with audience management and second screen applications used in themarketing strategies of television serials, have become concrete.

The high ratings of the serial Insider have kept the agenda of social media busy for a long time. Through 39 episodes with sharings and discussions made on social media platforms via the second screen, Insider became a trending topic both in Turkey and abroad. In the literature, social media platforms are considered to be an art channel of television. Harrington (2016) states that the television will get the Twitter art channel in motion, and Twitter will become a pre-condition of the entire viewing experience (p.331). In fact, we are facing a new viewing experience here. This viewing experience is gaining visibility by enabling the development of multi-screen social television. The content analysis conducted in this study shows that social television applications can contribute to the industry in various ways: they allowviewers to express their interest in, criticism of, and curiosity for the narrative and the characters, they facilitate the viewer's communication with the celebrities, and they make the viewer more involved in the narrative. Thus, social TV applications contribute to the growth of the media industry. 
In the new broadcasting ecosystem, the most important opportunity that the second screen and social television applications provide for the audience is interactivity. Television narratives still continue to take center stage in our everyday lives; they offer a way of building relationships and coming together as a community. As a new audience experience, social media enables viewers to share and discuss practices of interpretation and emotions with other audience members. Through the second screen, we can talk about what we watch on television, and we can ensure the involvement of our social environment in the discussion about the current episode or the next episode. In particular, TV audience members who watch a certain program through the second screen can read the text differently from that which the production firm aimed to communicate and can use the serial hashtags for their own purposes. As it is seen, through increased participation in the networked community, viewers do more than cooperating in the reconstruction of the text of the television. The Twitter analysis using the example of Insider exposes the use and reproduction strategies of text by the audience in a rather free way. On the other hand, the Instagram analysis shows how both broadcasters and brands have reached and interacted with second-screen users through industrygenerated content.

In this new broadcasting era, the way in which television content is written, produced, and consumed has significantly changed. With the use of the second screen, the way in which the audience watch television has also changed. As with other traditional broadcasting formats, the series industry in Turkey is in a transition period in terms of adapting second screen practices and content production in the new ecosystem. The business of integrating to this new environment has already created a competitive environment in the Turkish broadcasting industry. This particular example of the serial Insider shows us the reciprocal interaction between the industry and the audience, as well as the increasing influence of the audience on content production. Today, industry professionals are constantly trying new ways to increase ratings in this new ecosystem. Therefore, audience and content management strategies in the industry are changing, and they are changing according to the ratings of the series. In this new competitive ecosystem, it is obvious that the industry will be more inclined to adopt new ways of content and audience management. This study sheds light on the changing and developing broadcasting industry in terms of audience and content management. However, we need to examine how the audience experience is changing and how marketing strategies can be adopted to the new audience profile in further studies.

\section{References}

Arrojo, M. J.(2015). Social television as a new relationship between conventional TV and the audience: An analysis of its aims, processes, and results. International Journal of Social Science Studies, 3(4), 37-49.

Bilgin, N. (2014). Sosyal Bilimlerde İçerik Analizi. Ankara: Siyasal Kitabevi.

Binark, M., Yalçın, H., Karataş, Ş., \& Çomu, T. (2017). Sosyal Bilim Araştırmalarında Türkiye'de Veri Etiği Politikası: Sosyal Medya Ortamlarından Veri Toplanması. Sosyoloji Divanı. 5(9), 101-128. 
Bjur, J. (2012). Social television ecology - The misfits and new viewing practices. In A. Abruzzese, N. Barile, J. Gebhardt, \& J. Vincent(Eds), The New Television Ecosystem (pp. 175-192). Berlin: Peter Lang. Blake, J. (2017). Television and second screen interactiveTV in the age of social participation. New York: Routledge.

Braun, V., \&Clarke,V. (2014). What can 'thematic analysis'offer health and wellbeing researchers? International Journal of Qualitative Studies on Health and Well-being, 9(1), 26152. https://doi.org/10.3402/qhw.v9.26152.

Buschow, C., Schneider,B.,\&Ueberheide, S. (2014). Tweeting television: exploring communication activities on twitter while watching TV Communications. European Journal of Communication Research, 39(2), 129-149.

Dikmen, E.Ş. (2017). Türkiye'de Televizyon Yayınclığının Dönüşümü: Sosyal TV Yayıncılığı. Gümüşhane Üniversitesi İletişim Fakültesi Elektronik Dergisi, 5(1), 425-448.

Duncan, G.,\&Krommendam, H.(2014). The Future Face of Television. Leadership in the Changing World of Technology and Viewing Behaviour. Retrieved from https://www.spencerstuart.com/research-andinsight/the-future-face-of-television.

Ellis, J. (2000). Seeing Things: Television in the Age of Uncertainty. London: Cambridge University Press.

Evans, E. (2015). Layering engagement: the temporal dynamics of transmedia television.Storyworlds: $A$ Journal of Narrative Studies. 7(2), 111-128.

Gökçe, O. (2001). İçerik Çözümlemesi Teori-Metod-Uygulama. Konya: Selçuk Üniversitesi.

Harrington, S. (2016). Televizyonu tweetlemek: Canlı Tv, izleyiciler ve sosyal medya. In K. Weller, A. Burns, J. Burgess, M. Mahrt, \& C. Puschmann (Eds.), Twitter ve Toplum (pp. 325-337). İstanbul: Epsilon Yayıncilik.

Hay, J., \& Couldry, N. (2011). Rethinking Convergence/Culture, Cultural Studies, 25(4-5), 473-486.

Jenkins, H. (2001). Convergence? I diverge. Technology Review. Retrieved from http://web.mit.edu/cms/People/henry3/converge.pdf

Jenkins, H. (2004). The Cultural Logics of Media Convergence. International Journal of Cultural Studies, 7(1), 33-43. Retrieved from https://doi.org/10.1177/1367877904040603

Jenkins, H. (2006). Convergence culture: Where old and new media collide. New York: NYU Press.

Jenkins, H. (2007). Transforming fan culture into user-generated content. Confessions of an Aca-Fan [online]. Retrieved from http://henryjenkins.org/2007/05/transforming fan culture into.html

Jenkins, H. (2013). Is This the End of Television as We Know It? Retrieved from http://henryjenkins.org/2013/05/is-this-the-end-of-television-as-we-know-it.html

Jürgens, P., Jungherr, A., \& Schoen, H. (2011). Small worlds with a difference: New gatekeepers and the filtering of political information on Twitter. Proceedings of the 3rd International Web Science Conference, 21. Retrieved from http://andreasjungherr.net/wpcontent/uploads/2013/11/J\%C3\%BCrgens-Jungherr-Schoen-2011-Small-Worlds-with-aDifference.pdf

Katz, E. (2009).The end of television?: Its impact on the world (so far). ANNALS 623,6-18. 
Kirkpatrick, D., \&Tode, C.(2016). Twitter's role as second-screen leader is under attack. Retrieved from www.marketingdive.com/news/twitters-role-as-second-screen-leader-is-under-attack/ 431098/

Lavrakas, P. J. (2008). Random Sampling. Encyclopedia of Survey Research Methods. Retrieved from http://dx.doi.org/10.4135/9781412963947.n440

Marshall, P. D. (2010). Screens: television's dispersed'broadcast.'In T. Graeme \&T. Jinna (Eds.), Television Studies After TV Understanding Television in the Post-Broadcast Era (pp. 41-50). New York: Routledge.

Marwick, A., \& boyd, d. (2016). Dürüstçe tweetlerim duyguyla tweetlerim - Twitter kullanıcıları, bağlam çöküşü ve hayali izleyiciler. In H. Hülür \& C. Yaşin (Eds.), Yeni Medya Kullanıcının Yükselişisi (pp. 108-132). Ankara: Ütopya Yayınevi.

Matthews, J. (2010). New Cultural Media and Convergence: Empirical and Critical Interrogations. Contribution at Proceedings of New Media and Information 2009 International Symposium, Athènes, Helios.

Nielsen (2013). The Follow Back: Understanding the Two-Way Causal Influence between Twitter Activity and TV Viewership. Retrieved from http://goo.ql/cKHG8y.

Okur, Y. (2017, July 11). The audience management strategy of Insider. Interview conducted by Selin Çetindağ in İstanbul.

Okur, Y. (2017, September). Anthropology of Media in Turkey: Theory, Methodology, and the Future Orientations Workshop. Talk on the Turkish drama industry at Kadir Has Üniversitesi, İstanbul.

Pearson, R. (2010). Fandom in the digital era. Popular Communication, 8, 84-95.

Peltekoğlu, F.B.(2016). Halkla ilişkiler nedir? İstanbul: Beta Yayıncılık.

Quintas-Froufe, N., \&González-Neir, A. (2014). Active audiences: social audience participation in television. Comunicar, 43, 83-90. https://doi.org/10.3916/C43-2014-08

Sezen, D. (2016). Dijital Sonrası Hayran Kültürünün Dönüşümü Üzerine. In N. Timisi (Ed.), Dijital Kavramlar, Olanaklar, Deneyim/er (pp. 153-177). İstanbul: Kalkedon Yayınları.

Storsul, T., \& Stuedahl, D., Eds. (2007). Ambivalence Towards Convergence Digitalization and Media Change. Sweden: Nordicom.

Wadlington, J. (2016). How to: Advanced search on Twitter. Retrieved from https://business.twitter.com/en/blog/how-to-advanced-search-on-twitter.html

Wang, L. (2015). An exploratory thematic analysis on viewers' involvement with haul video personaes-taking bethany mota as a case study (master's thesis). Wake Forest University Graduate School of Arts and Sciences, Winston-Salem, North Carolina.

Yıldırım, A., \& Şimşek, H. (2003). Sosyal Bilimlerde Nitel Araştırma Yöntemleri. Ankara: Seçkin. 